\title{
Effect of Multimicronutrient on Fruit Quality and Shelf Life of Aonla (Emblica officinalis Gaertn.) Cv. Gujarat Aonla-1
}

\author{
N.B. Ambaliya*, M.M. Masu, D.A. Sojitra and H.M. Raut
}

Department of Horticulture, B. A. College of Agriculture, Anand Agricultural University, Anand 388110, Gujarat, India

*Corresponding author

\begin{tabular}{l} 
K e y w o r d s \\
$\begin{array}{l}\text { Multimicronutrient, } \\
\text { Shelf life, Total } \\
\text { soluble solids and } \\
\text { ascorbic acid }\end{array}$ \\
Article Info \\
$\begin{array}{l}\text { Accepted: } \\
\text { 26 September } 2018 \\
\text { Available Online: } \\
10 \text { October } 2018\end{array}$ \\
\hline
\end{tabular}

\section{A B S T R A C T}

The research experiment was carried out on "Effect of multimicronutrient on fruit quality and shelf life of aonla (Emblica officinalis Gaertn.) cv. Gujarat Aonla-1". The experiment was conducted during kharif - Rabi season of the year 2017-18 at Horticultural Research Farm, Department of Horticulture, B. A. College of Agriculture, Anand Agricultural University, Anand. There were three levels of soil application of multimicronutrient (Grade-V) viz., $\mathrm{S}_{1}$ - Control, $\mathrm{S}_{2}-250 \mathrm{~g} /$ tree and $\mathrm{S}_{3}-500 \mathrm{~g} /$ tree and three levels of foliar application of multimicronutrient (Grade-IV) viz., $\mathrm{F}_{1}$-Control, $\mathrm{F}_{2}-1 \%$ spray and $\mathrm{F}_{3}-2 \%$ spray. Multimicronutrient (Grade-V) was given as soil application at onset of monsoon and multimicronutrient (Grade-IV) was foliar sprayed at pin head and pea stage. Among all the treatments, $\mathrm{F}_{2}(1 \%$ spray of multimicronutrient Grade-IV) treatment was most effective treatment and which was recorded significantly maximum total soluble solids, shelf life, ascorbic acid and minimum acidity and internal necrosis affected fruits. There were nonsignificant effect of soil application of multimicronutrient (Grade-V) on total soluble solids (TSS), acidity and shelf life whereas, there were significant effect of soil application of multimicronutrient (Grade-V) on ascorbic acid and internal necrosis affected fruits. Among all the treatments, $S_{3}(500 \mathrm{~g} /$ tree multimicronutrient Grade-V) treatment was recorded significantly maximum ascorbic acid and minimum internal necrosis affected fruits.

\section{Introduction}

Aonla tree is small to medium in size. It is evergreen in tropics and as deciduous in subtropical conditions. Aonla is drought hardy fruit crop which is characterized by deep root system and exhibits deciduous nature due to abscission and shedding of determinate shoot. The chemical composition of aonla is found to be influenced by environmental factors. It has been found that the chemical parameters viz. total soluble solids, acidity, sugars, ascorbic acid, etc., change during growth and development of fruits. Total soluble solids, sugars and ascorbic acid gradually increased reaching the maximum at maturity, whereas acidity, phenol and tannin content decreased up to the minimum at maturity. The fruit weight, length and diameter showed a constant increased till the time of maturity (Ojha and Pathak, 1993). Internal necrosis of fruit is major problems in reducing yield and quality 
of aonla fruit.The shelf-life of aonla fruit is 12-15 days under normal conditions. It becomes difficult to process entire fruit production in short span of time. At the peak harvest season, the availability of the fruits exceeds whereas the demand and the market price falls very low. Micronutrients also help in the uptake of major nutrients and play an active role in the plant metabolism process starting from cell wall development to respiration, photosynthesis, chlorophyll formation, enzyme activity hormone synthesis, nitrogen fixation and reduction (Das, 2003). Soil and foliar application of multimicronutrient is important for recover the trees from noticed deficiency for healthy growth of tree and could achieve a good quality fruit. Foliar application is based on the principle that the nutrients are quickly absorbed by leaves and transported to different part of the plant to fulfill the functional requirement of nutrition. Foliar application of the nutrient is obviously an ideal way to avoiding the problem of nutrient availability.

\section{Materials and Methods}

The experiment was conducted on "Effect of multimicronutrient on fruit quality and shelf life of aonla (Emblica officinalis Gaertn.) cv. Gujarat Aonla -1" at Horticultural Research Farm and P. G. Laboratory, Department of Horticulture, B. A. College of Agriculture, Anand Agricultural University, Anand duringKharif-Rabi season of the year 201718.For conducting the study, 23 year old uniform tree of aonla were selected and experiment was laid out in Completely Randomized Design with factorial concept (FCRD). There were three levels of soil application viz., $\mathrm{S}_{1}-$ Control, $\mathrm{S}_{2}-250 \mathrm{~g} /$ tree multimicronutrient (Grade-V) and $\mathrm{S}_{3}-500$ $\mathrm{g} /$ tree multimicronutrient (Grade-V) and three levels of foliar application viz., $\mathrm{F}_{1}-\mathrm{Control}, \mathrm{F}_{2-}$ $1 \%$ Spray of multimicronutrient (Grade-IV) and $\mathrm{F}_{3}-2 \%$ Spray of multimicronutrient
(Grade-IV). Multimicronutrient (Grade-V) was soil application at onset of monsoon and multimicronutrient (Grade-IV) was foliar sprayed at pin head and pea stage. Multimicronutrient (Grade IV) is combination of $4.0 \%$ Iron, $1.0 \%$ Manganese, $6.0 \%$ Zinc, $0.5 \%$ Copper and $0.5 \%$ Boron and multimicronutrient (Grade $\mathrm{V}$ ) is combination of $2.0 \%$ Iron, $0.5 \%$ Manganese, $5.0 \%$ Zinc, $0.2 \%$ Copper, and $0.5 \%$ Boron. Multimicronutrient (Grade-IV) was sprayed at pin head and pea stage whereas, soil application of multimicronutrient (Grade-V) was given at onset of monsoon. The soil of experiment site was sandy loam. Recommended dose of farm yard manure and NPK fertilizers were given as common dose in all the treatments. The mature and uniform sized fruits were harvested from the respective trees where observations were recorded regarding the quality parameters of the fruits.

\section{Results and Discussion}

The results obtained from the research experiment on effect of multimicronutrient on fruit quality and shelf life of aonla are presented in Table 1 and 2.

There was non-significant effect of soil application of multimicronutrient (Grade-V) on quality parameter viz. total toluble solids (TSS), acidity and shelf life whereas, there were significant effect of soil application of multimicronutrient (Grade-V) on ascorbic acid and internal necrosis affected fruits. Among all the treatments, $\mathrm{S}_{3} \quad(500 \mathrm{~g} / \mathrm{tree}$ multimicronutrient Grade-V) treatment was recorded significantly minimum internal necrosis affected fruits $(4.4 \%)$ and maximum ascorbic acid (827.15 mg/100 g pulp). The significantly minimum internal necrosis affected fruits was recorded with the soil application of $500 \mathrm{~g} /$ tree multimicronutrient (Grade-V) might be due to incorporation of boron in the soil that is proved beneficial 
effect to minimize the internal necrosis physiological disorder of aonla by affecting the activities of several enzyme oxidase and sucrose. These findings are in accordance with the findings of Singh et al., (2001), Patel et al., (2003) and Katiyar et al., (2010) in aonla.

Whereas, the significantly maximum ascorbic acid $(\mathrm{mg} / 100 \mathrm{~g}$ pulp) was recorded with the soil application of $500 \mathrm{~g} /$ tree multi micronutrients (Grade-V). It might be due to higher level of sugar due to micronutrient application including boron might be the possible cause behind increase in ascorbic acid content which is synthesized from sugar. Similar trend was also observed by
Saraswathy et al., (2002) in sapota and Singh et al., (2003) in mango.

The foliar application of multimicronutrient was significantly influenced on internal necrosis affected fruits. Among all the treatments, $\quad \mathrm{F}_{2} \quad(1 \quad \%$ spray of multimicronutrient Grade-IV) treatment was recorded significantly minimum internal necrosis affected fruits $(2 \%)$. It might be due to the fact that boron has significant role in mobilization of food material from source to sink as a result accumulate the photosynthates which control internal necrosis affected fruits. The results are also in accordance with the findings of Singh et al., (2001) in aonla.

Table.1 Effect of soil and foliar application of multimicronutrient on internal necrosis affected fruit and ascorbic acid of aonla $\mathrm{Cv}$. Gujarat Aonla-1

\begin{tabular}{|c|c|c|}
\hline Treatments & $\begin{array}{l}\text { internal } \\
\text { necrosis } \\
\text { affected } \\
\text { fruit } \\
(\%)\end{array}$ & $\begin{array}{c}\text { Ascorbic } \\
\text { acid } \\
\text { (mg/100 } \\
\text { g pulp) }\end{array}$ \\
\hline \multicolumn{3}{|l|}{ A. Soil application (S) } \\
\hline$S_{1}:$ Control & 7.11 & 789.51 \\
\hline$S_{2}: 250 \mathrm{~g} /$ tree multimicronutrient (Grade-V) & 6.00 & 810.63 \\
\hline$S_{3}: 500 \mathrm{~g} /$ tree multimicronutrient (Grade-V) & 4.44 & 827.15 \\
\hline S.Em. \pm & 0.19 & 4.84 \\
\hline C.D. at $5 \%$ & 0.57 & 14.39 \\
\hline \multicolumn{3}{|l|}{ B. Foliar application (F) } \\
\hline $\mathrm{F}_{1}:$ Control & 9.89 & 749.11 \\
\hline$F_{2}: 1 \%$ Spray of multimicronutrient (Grade-IV) & 2.00 & 854.86 \\
\hline$F_{3}: 2 \%$ Spray of multimicronutrient (Grade-IV) & 5.67 & 823.33 \\
\hline S.Em. \pm & 0.19 & 4.84 \\
\hline C.D. at $5 \%$ & 0.57 & 14.39 \\
\hline \multicolumn{3}{|l|}{$\mathbf{S} \times \mathbf{F}$ interaction } \\
\hline S.Em. \pm & 0.33 & 8.39 \\
\hline C.D. at 5\% & NS & 24.93 \\
\hline C.V. \% & 9.87 & 1.80 \\
\hline
\end{tabular}


Table.2 Effect of soil and foliar application of multimicronutrient on Total Soluble Solids $\left({ }^{0}\right.$ Brix) acidity and shelf life of aonla Cv. Gujarat Aonla-1

\begin{tabular}{|c|c|c|c|}
\hline Treatments & $\begin{array}{c}\text { TSS } \\
\left({ }^{0} \text { Brix }\right)\end{array}$ & $\begin{array}{c}\text { Acidity } \\
(\%)\end{array}$ & $\begin{array}{l}\text { Shelf } \\
\text { life } \\
\text { (Days) }\end{array}$ \\
\hline \multicolumn{4}{|l|}{ A. Soil application (S) } \\
\hline$S_{1}$ : Control & 14.97 & 1.87 & 17.62 \\
\hline$S_{2}: 250 \mathrm{~g} /$ tree multimicronutrient (Grade-V) & 15.10 & 1.85 & 18.44 \\
\hline$S_{3}: 500 \mathrm{~g} /$ tree multimicronutrient (Grade-V) & 15.41 & 1.83 & 18.71 \\
\hline $\begin{array}{lr}\text { S.Em. } \pm \\
\end{array}$ & 0.23 & 0.02 & 0.56 \\
\hline C.D. at 5\% & NS & NS & NS \\
\hline \multicolumn{4}{|l|}{ B. Foliar application (F) } \\
\hline $\mathrm{F}_{1}:$ Control & 14.51 & 1.93 & 16.80 \\
\hline$F_{2}: 1 \%$ Spray of multimicronutrient (Grade-IV) & 15.89 & 1.74 & 19.82 \\
\hline $\mathrm{F}_{3}: 2 \%$ Spray of multimicronutrient (Grade-IV) & 15.08 & 1.87 & 18.15 \\
\hline S.Em. \pm & 0.23 & 0.02 & 0.56 \\
\hline C.D. at 5\% & 0.69 & 0.07 & 1.67 \\
\hline \multicolumn{4}{|l|}{$\mathrm{S} \times \mathrm{F}$ Interaction } \\
\hline S.Em. \pm & 0.40 & 0.04 & 0.97 \\
\hline C.D. at $5 \%$ & NS & NS & NS \\
\hline C.V. \% & 4.66 & 4.01 & 9.26 \\
\hline
\end{tabular}

The foliar application of multimicronutrient was significantly influenced on Total Soluble Solids and acidity. Among all the treatments, $\mathrm{F}_{2}$ (1\% spray of multimicronutrient GradeIV) treatment was recorded significantly maximum Total Soluble Solids $\left(15.89{ }^{0}\right.$ Brix $)$ and minimum acidity $(1.74 \%)$. The significantly maximum total soluble solids was recorded with foliar spray of $1 \%$ multimicronutrient (Grade-IV) might be due to zinc increased the synthesis of tryptophan that is a precursor of auxin. It plays a key role in protein synthesis, sugar metabolism and maintains the integral structure. On the other hand, boron may be associated with the cell membrane where it could be complex with sugar molecules and facilitates its passage across the membrane. The significantly minimum acidity was recorded with foliar spray of $1 \%$ multimicronutrient (Grade-IV) might be due to zinc increase the synthesis of tryptophan that is a precursor of auxin. It plays a key role in protein synthesis, sugar metabolism and maintains the integral structure. On the other hand, boron may be associated with the cell membrane where it could be complex with sugar molecules and facilitates its passage across the membrane that might be the reason for increased acidity. Similar results were found by Singh et al., (2001), Verma et al., (2008), Vishwakarma et al., (2013), Shukla et al., (2009), Singh et al., (2009) and Chandra and Singh (2015) in aonla.

There were significant effects of foliar application of multimicronutrient on shelf life. Among all the treatments, $\mathrm{F}_{2}(1 \%$ spray of multimicronutrient Grade-IV) treatment was most effective treatment and it was recorded significantly maximum shelf life (19.82 day) and It might be due to increase in concentration of boron of middle lamella of cell wall which provide physical strength to 
cell wall and improved fruit colour development and appearance. These findings are in accordance with the findings of Bhatt et al., (2012) and Singh et al., (2012) in mango.

The interaction effect between soil and foliar application of multimicronutrient was found non-significant effect on internal necrosis affected fruit, shelf life, total soluble solids and acidity whereas, there was significant effect on ascorbic acid.

The result obtained from research experiment concluded that, $1 \%$ foliar spray of multimicronutrient (Grade-IV) at pin head and pea stage recorded minimum internal necrosis affected fruit and acidity whereas, maximum total soluble solids, ascorbic acid and shelf life in aonla fruit cv. Gujarat Aonla1 .

\section{References}

Bhatt, A. Mishra., N. K. Mishra, D. S. and Singh, C. P. (2012). Foliar application of potassium, calcium, zinc and boron enhanced yield, quality and shelf life of mango. Hort Flora Res. Spectrum, 1(4), 300-305.

Chandra. R. and Singh., K. K. (2015). Foliar application of zinc sulphate, magnesium sulphate and copper sulphate on the yield and quality of aonla (Emblica officinallis Gaertn.) cv. "NA-7" under Garhwal Himalaya. J. of Med. Plants studies. 3(5), 42-45.

Das. D. K. (2003). Micronutreints: Their behaviors in soil and plant. Kalyani publication, Ludhiana pp. 1-2

Katiyar, P. N. Singh. J. P. and Singh. P. C. (2010). Effect of NPK with and without boron and farm yard manure on yield and fruit quality of aonla (Emblica officinalis). Cur Adv in Agric Sci. 2(1), 29-31.
Ojha. C. M. and Pathak., R. K. (1993). Changes in chemical composition of aonla cultivars during growth and development of fruits. Prog. Hort., 25 (1-2), 42-46.

Patel, K. P. Ramani, V. P. Patel, K. C. and George, V. (2003). Role of micronutrient concentration in management of physiological disorders in amla.; A paper presented in national seminar on production and utilization of Aonla held at Salem, 8-10 Aug., 119127.

Saraswathy. K. P. Vishwakarma., L. G. Kolambe, S. S. and Sharma, M. C. (2002). Effect of soil and foliar application of micronutrient on growth, yield and quality of sapota (Achras sapota L.) cv. PKM-1. Indian J. Hort., 57(3), 215-219.

Shukla. A.K. (2009). Effect of foliar application of calcium and boron on growth, productivity and quality of Indian gooseberry (Emblica officinalis Gaertn.), Indian J. of Agri. Sci; 81 (7), 628-32.

Singh. H. K. Srivastava, A. K., Dwivedi, R., and Kumar, P. (2001). Effect of foliar feeding of micronutrients on plant growth, fruit quality, yield and internal fruit necrosis of aonla (Emblica officinalis Gaertn.) cv. Francis. Prog. Hort., 33(1), 80-83.

Singh. V. K. Bhriguvanshi., S. R. Yadava., L. P. and Chatterjee, C. (2009). Effect of micronutrients on growth and yield of mango cv. Dashehari. The Asian J. Hort., 4 (1), 112-115

Singh. Y. P., Tiwari. J. P., \&Misra, K. K. (2003). Effect of micronutrients on fruit yield and physico-chemical characters of mango cv. Dashehari. Prog. Hort., 35(1), 34-37.

Singh, P. C. Gangwar, R. S. and Singh, V. K. (2012). Effect of micronutrients spray on fruit drop, fruit quality and yield of 
aonla cv. Banarasi. Hort Flora Research Spectrum, 1(1), 73-76.

Verma, R. S. Singh, P. C., and Chaturvedi, O. P. (2008). Effect of foliar sprays of zinc and boron on the physical parameters of aonla (Emblica officinalis Gaertn.) fruits cv. Banarasi. Asian J.Hort, 3(2), 344-345.
Vishwakarma, G. A. L. Yadav. H. K. Singh and Jagveer Singh. (2013). Effect of foliar feeding of Calcium and Boron on yield and quality of aonla cv. NA-6. Plant archives, 13(2), 1135-1138.

\section{How to cite this article:}

Ambaliya, N.B., M.M. Masu, D.A. Sojitra and Raut, H.M. 2018. Effect of Multimicronutrient on Fruit Quality and Shelf Life of Aonla (Emblica officinalis Gaertn.) Cv. Gujarat Aonla-1. Int.J.Curr.Microbiol.App.Sci. 7(10): 3609-3614. doi: https://doi.org/10.20546/ijcmas.2018.710.418 